\author{
A.K. Sembekov ${ }^{1}$, Zh.O. Lukpanova ${ }^{2}$, Zh.A. Toyzhigitova $^{3}$, N.N. Tyupakova ${ }^{4}$ \\ ${ }^{l}$ Karaganda Economic University of Kazpotrebsoyuz \\ ${ }^{2,3}$ Kazakh University of Economics, Finance and International Trade \\ ${ }^{4}$ Kuban State Agrarian University \\ 'amir_sembekov@mail.ru, ${ }^{2}$ zhanar_or@mail.ru, \\ 3ms_t.zhanara@mail.ru, ${ }^{4}$ tyupakova.nina@mail.ru \\ ${ }^{1}$ https://orcid.org/0000-0001-5034-4651, ${ }^{2}$ http://orsid.org/0000-0002-2552-4332, \\ ${ }^{3}$ http://orsid.org/0000-0003-0211-8662, ${ }^{4}$ https://orcid.org/0000-0002-9562-1074 \\ ${ }^{1}$ Scopus Author ID: 57189096398, ${ }^{2}$ Scopus Author ID: 57189090791, ${ }^{3}$ Scopus Author ID: 57199300450
}

\title{
The tax policy of the Republic of Kazakhstan in the context of modernization
}

\begin{abstract}
Object: The aim of the study is to identify the results of tax reforms, assess the current state of the tax system of the Republic of Kazakhstan, as well as to identify problems and determine the main directions for improving the tax system of Kazakhstan.

Methods: The research methods - system analysis, economic and statistical data processing, comparison and generalization, scientific analysis and synthesis.

Findings: The article analyzes the current tax policy in the Republic of Kazakhstan, namely the impact of tax reforms on the economy of Kazakhstan, with an emphasis on recent tax reforms. An analysis of tax revenues and a comparative analysis of structural changes in the budget in recent years, with an emphasis on the main production taxes, such as corporate income tax, value added tax, taxes on international trade and foreign operations.

Conclusions: The study revealed the problems of the effectiveness of tax reforms in Kazakhstan from the standpoint of their compliance with modern requirements. The article notes that the modern tax policy of Kazakhstan should be aimed at supporting small and medium-sized businesses, stimulating the non-resource sector of the economy. In particular, it proposes a policy to stimulate the production of agricultural processing enterprises and the food industry, justifies the need for tax incentives for food producers in terms of reducing the value added tax. In the context of the EAEU integration trade, it is necessary to adopt tax incentives to reduce the total tax burden on products of the nonresource sector of the economy, and to resolve the administrative and customs problems of the union.
\end{abstract}

Keywords: tax reforms, tax revenues, tax benefits, budget revenues, tax rate, taxes, tax policy, income.

\section{Introduction}

Taxation is an important public policy tool. In the state's financial policy, tax policy is one of the most important factors in ensuring economic growth, developing entrepreneurial activity, eliminating the shadow economy, and attracting full-scale foreign investment to the country. In order to overcome the negative consequences of the impact of taxes on economic development, an objective need arose to analyze the structure and dynamics of tax revenues in the country's budget. In this regard, it is relevant to determine the impact of tax reforms on state budget revenues, since a properly constructed tax policy has a positive effect on increasing tax revenues to the budget, increasing the welfare of the country as a whole, and improving the living standards of the population. In this regard, the chosen research topic is relevant.

\section{Literature Review}

The research methodology was based on the study of the works of the economic science classics, modern scientific works of foreign and domestic scientists and economists in the field of analysis of tax reforms using theoretical generalization, system and comparative analysis, and the method of statistical data processing. Among the theoretical researchers who have made a real contribution to the development of the general theory of taxation, one can distinguish such scientists as: N. Machiavelli, T. Hobbes, F. Bacon, S. Montesquieu, F-M Voltaire; J. Locke, P.A. Holbach, P. Prudon, B. Franklin, in whose works much attention is paid to the importance of taxation; U. Petgi, A. Smith, D. Ricardo, J. Ciamond de Sismondi, N. Canard, D. Mill, whose works contain a deep justification of the economic nature of taxes, principles of taxation, and the distribution of the tax burden. Among modern foreign researchers working on tax reform issues, one cannot fail to mention M. Alle, C. Heidi, J. Slemrod, N. Stem, R. Gesneri, H. Aaron. 
Thus, the English economist John Maynard Keynes (1883-1946) made an outstanding contribution to the development of tax theory. He paid much attention to tax regulation, emphasizing that tax policy can have a powerful effect on economic growth, increasing employment, stimulating the propensity to consume, etc. J. Keynes believed that with the help of taxes it is useful to take out the income placed in savings, to finance current public expenditures from them, and, most importantly, to invest. Considering the role of taxes in regulating the economy, Keynes drew attention to the positive role of relatively high taxes, citing the fact that lower tax rates are accompanied by lower budget revenues and economic instability of the state (Keynes, 1936)

A vocal supporter of Keynesianism was Nobel laureate Paul Samuelson. P. Samuelson considered taxes and tax policy as important tools in regulating the economy and believed that with the help of taxes macroeconomic growth and stability are stimulated, unemployment and inflation are reduced, and economic growth is encouraged. Analyzing the role of fiscal policy in regulating the economy, Samuelson pointed out the contradictory processes that must be considered when building the tax system (Samuelson, 1952).

If we consider modern foreign scientists and economists, the greatest interest are caused by the works related to tax reform in the field of supporting the business sector and stimulating the non-resource sector of the economy. Thus, such scientists as J. Feehan and M. Matsumoto, who in their works consider tax instruments to support industrial infrastructure, including the processing of raw materials and materials, agriculture (Feehan, Matsumoto, 2002), should be noted. Jack. Diamond, Fiorella Fiore, Werner Roger also emphasize the direct impact of fiscal regimes on population growth and employment, and emphasize the stimulating function of taxes (Fiore, 1999; Diamond, 2003).

In 2000, many foreign economists advocated tax cuts and thus boost the economy and remove entrepreneurs from the shadow business. Thus, J. Toy, in his article "The Financial Crisis and Budget Reforms in Developing Countries", proposes to optimize the tax policy of the state by cutting individual income taxes (Toye, 2000).

D.V. Jorgenson is a supporter of social modernization. In his textbook on investments, he talks about the need for tax reform by reducing the tax burden on industrial infrastructure (Jorgenson, 2001).

Stephen M. Rosenthal, Victor A. Canto, Andy Wiese are not supporters of excessive tax benefits, since they believe that such a policy is not fair enough and can adversely affect the state budget, but nevertheless, they are for a reasonable tax policy and moderate tax rates ( Rosenthal, 2017).

Among the scientific works in which, along with the problems of formation and functioning of taxes, as an area of knowledge of financial science, the economic content and importance of taxation in national economic systems are considered, it is worth noting the work of such Russian scientists as N.P. Biryukov, L.P. Golubeva, L.I. Goncharenko, R.S. Greenberg, Yu.B. Ivanov, M.V. Karaseva, N.L. Lykova, I.A. Mayburov, L.P. Pavlova, S.G. Pepelyaev, M.V. Romanovsky, B.M. Sabanti, D.G. Chernik, A.S. Sharov, S.D. Shatalov, E.B. Shuvalova, T.F. Yutkina et al.

Ruta Banelene, Borisas Melnikas, Rolandas Strazdas, Eligius Tolochka in their article "Innovation Activities and the Impact of R\&D Investments on Economic Growth: Evaluation and Modeling" offer effective tools to support innovation (Banelene, 2018).

In Kazakhstan, the works of R.A. Alshanov, T.A. Ashimbayev, A.D. Baiduysenova, R.E. Elemesova, B.Zh. Ermekbaeva, A.B. Zeynelgabdina, E.K. Idrissova, N.I. Inkerbayeva, A.K. Koshanova, V.D. Melnikova, N.E. Nauryzbayev, A.A. Nurumova, F.S. Seidakhmetova etc. are devoted to the issues of analyzing the reform of the tax system.

\section{Methods}

The study analyzed the impact of tax reforms on the economy of the Republic of Kazakhstan, conducted a comparative analysis of tax revenues to the budget and highlighted the main taxes in the state budget.

During the study, the object was the tax system of the Republic of Kazakhstan. The subject of the study was the tax reforms carried out in the Republic of Kazakhstan and their effectiveness.

The research methodology is based on the principles of systemic structural analysis, based on the application of the methods of economic and statistical data processing, comparison and generalization, scientific analysis and synthesis.

The problems of the tax reforms effectiveness in Kazakhstan are studied from the standpoint of their compliance with the requirements of modern realities. Quantitative parameters (volume, dynamics and structure of tax revenues to the budget) led to the conclusion about the structure of tax revenues in the budget, the completeness of their collection, and the lack of targeted tax benefits. The dynamics of tax revenues over a number of years has shown an analysis of the effect of tax changes on tax collection. 
Results

In recent years, significant changes have occurred in the tax legislation of the Republic of Kazakhstan, which have positively affected both the development of the tax system and the stimulation of the production infrastructure, including business environment as a whole. Thus, under special tax regimes the burden on small businesses has been significantly reduced. Such a measure has positively affected the growth of entrepreneurs in the country and the increase in tax revenues to the budget.

The dramatic changes in tax legislation that have taken place in recent years have affected changes in tax revenues. This can specifically be seen in the examples of such major budget-forming taxes as CIT, VAT, taxes on international trade and foreign operations, etc.

Let us analyze the tax revenues for basic taxes over the past 5 years. Thus, in 2014 tax revenues accounted for KZT 5,115,743 million. In 2018 tax revenues increased and reached KZT 7,890,048 million. Over the past two years, the state budget has increased significantly. Thus, in 2018 the growth rate of tax revenues compared to 2014 amounted to $154 \%$. In 2018 the annual revenue plan was exceeded at all budget levels (State Budget, SB - 102.2\%, Republican Budget, RB - 101.2\% and Local Budget, LB - 104.6\%). The largest increase in state budget revenues is observed in 2017, and the growth is $20 \%$ or KZT 1,674 billion.

The share of taxes in budget revenues over the past 5 years averages $66.2 \%$ (Table 1). In general, the created favorable conditions for doing business allowed to involve additional 72 thousand enterprises in the economic turnover. The number of operating enterprises exceeded 1.5 million $(1,448,414$ in 2017, 1,520,101 in 2018).

Table 1. The share of tax revenues in state budget revenues in recent years

\begin{tabular}{|l|c|c|c|c|c|}
\hline \multicolumn{1}{|c|}{ Indicators } & $\begin{array}{c}\text { Report for } \\
2014\end{array}$ & $\begin{array}{c}\text { Report for } \\
2015\end{array}$ & $\begin{array}{c}\text { Report for } \\
2016\end{array}$ & $\begin{array}{c}\text { Report for } \\
2017\end{array}$ & $\begin{array}{c}\text { Report for } \\
2018\end{array}$ \\
\hline $\begin{array}{l}\text { Revenues, } \\
\text { million KZT }\end{array}$ & 7321277 & 7634805 & 9308485 & 11567691 & 10808573 \\
\hline Tax revenues, million KZT & 5115743 & 4883913 & 6023263 & 6810851 & 7890048 \\
\hline $\begin{array}{l}\text { The share of taxes in budget } \\
\text { revenues, \% }\end{array}$ & 69,9 & 64,0 & 64,7 & 58,9 & $73 \%$ \\
\hline Note: Compiled by the author according to the Ministry of Finance of the Republic of Kazakhstan \\
\hline
\end{tabular}

Considering tax revenues over the past few years by type of tax, we get the following picture (Table 2). The first place in the volume of tax revenues is occupied by CIT - its share is $25 \%$, VAT takes the second place with $19 \%$, taxes on international trade and foreign operations account for $18 \%$ and take the third place, individual income tax takes the fourth place on receipt with $12 \%$ and one more budget-forming tax - social tax is the fifth, its share is $9.5 \%$ in budget tax revenues (Chaplinska, 2016). Only $8.0 \%$ falls on social tax, $3.1 \%$ on property taxes (including land tax, transport tax, property tax), and $2.2 \%$ falls on excise taxes.

Table 2. Analysis of the main taxes in the state budget of the Republic of Kazakhstan in recent years, million KZT

\begin{tabular}{|l|c|c|c|c|c|}
\hline \multicolumn{1}{|c|}{ Indicators } & 2014 & 2015 & 2016 & 2017 & 2018 \\
\hline Revenues & $7,321,277$ & $7,634,805$ & $9,308,485$ & $11,567,691$ & $10,808,573$ \\
\hline Tax Revenues & $5,115,743$ & $4,883,913$ & $6,023,263$ & $6,810,851$ & $7,890,048$ \\
\hline Corporate income tax & $1,169,667$ & $1,224,645$ & $1,437,365$ & $1,538,785$ & $1,687,577$ \\
\hline Individual income tax & 552,280 & 598,807 & 691,778 & 750,212 & 838,394 \\
\hline Social tax & 427985 & 464674 & 530440 & 576607 & 618505 \\
\hline Value added tax & 1198170 & 944438 & 1495682 & 1664699 & 2034314 \\
\hline $\begin{array}{l}\text { Taxes on international trade } \\
\text { and foreign operations }\end{array}$ & 880063 & 951807 & 1196919 & 1422717 \\
\hline Excise taxes & 147 057 & 161068 & 205231 & 255994 & 311856 \\
\hline Note: Compiled by the author according to the Ministry of Finance of the Republic of Kazakhstan \\
\hline
\end{tabular}

It should be noted that over the past 5 years the budget has been executed, but with a deficit. If we consider the dynamics of tax revenues over the past few years, then overall growth is observed (Figure 1). 


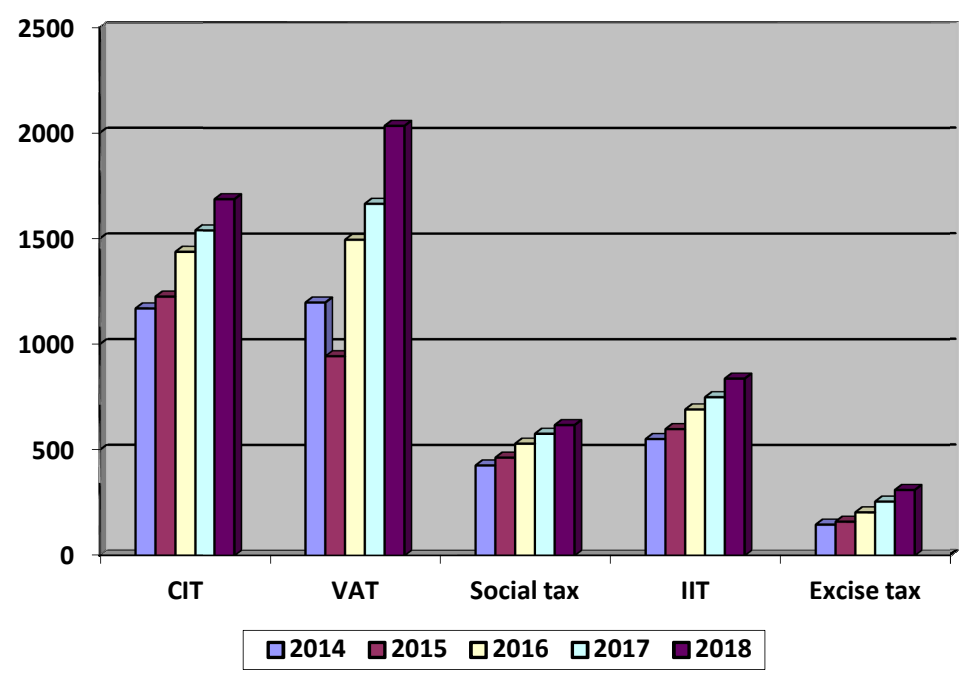

Figure 1. Dynamics and structure of tax revenues of the state budget of the Republic of Kazakhstan for 2013-2018, billion KZT

Note: Compiled by the author according to the Ministry of Finance of the Republic of Kazakhstan

In general, taxes occupy $64 \%$ of budget revenues, $32 \%$ account for official transfers. Non-tax revenues account for only $2.9 \%$, and about $1 \%$ account for the proceeds from the sale of fixed capital (Table 3 ).

Next, we consider the impact of changes in the main types of taxes. The most significant tax is corporate income tax. The payment of this tax is the highest burden for entrepreneurs. The share of CIT is increasing from year to year. For example, in 2018 the plan for CIT was 1,595 billion KZT, and revenues amounted to 1,687 billion KZT, so the percentage of completion is $105.7 \%$.

The payment of this tax represents the highest burden for entrepreneurs, therefore, the share of CIT in the tax revenues of the RB is quite high.

Table 3. Analysis of the actual CIT income and its share in the republican budget in recent years, mln. KZT

\begin{tabular}{|c|c|c|c|c|}
\hline Indicators & $\begin{array}{l}\text { Report for } \\
2015\end{array}$ & $\begin{array}{l}\text { Report for } \\
2016\end{array}$ & $\begin{array}{c}\text { Report for } \\
2017\end{array}$ & $\begin{array}{c}\text { Report for } \\
2018\end{array}$ \\
\hline Revenues & $6,136,968$ & $7,662,220$ & $9,691,789$ & $8,789,005$ \\
\hline Tax revenues, including & $3,332,925$ & $4,275,887$ & $4,848,028$ & $5,694,904$ \\
\hline Corporate income tax & $1,224,645$ & $1,437,365$ & $1,538,785$ & $1,687,577$ \\
\hline The CIT share in revenues of the RB & 19.9 & 18.8 & 15.8 & 19.2 \\
\hline The CIT share in tax revenues of the RB & 36.7 & 33.6 & 31.7 & 29.6 \\
\hline
\end{tabular}

Another main production payment is VAT, its share is $23.9 \%$. Since January 1,2009 , there have also been changes in the mechanism for calculating and collecting VAT. The VAT rate has been reduced from $13 \%$ to $12 \%$. (Tax Code of the Republic of Kazakhstan, 2017). This made Kazakhstan's VAT rate one of the lowest in the world among the standard rates of this tax.

In 2018 , the VAT was executed at $103.5 \%$ and revenues amounted to 2034.3 billion KZT. The data show the non-fulfillment of the VAT plan in 2015, this is due to the fact that the amount of VAT refunds from the budget has increased in recent years, as well as due to the release of VAT on goods transported within the Eurasian Economic Union (Table 4).

Table 4. Forecast fulfillment of VAT receipts to the state budget for 2015-2018, billion KZT

\begin{tabular}{|c|c|c|c|}
\hline Year & Forecast-plan & Actual receipt & Execution percentage \\
\hline 2015 & 945.7 & 944.4 & 99.9 \\
\hline 2016 & $1,445.2$ & $1,495.7$ & 103.5 \\
\hline 2017 & $1,650.5$ & $1,664.7$ & 100.9 \\
\hline 2018 & $1,965.0$ & $2,034.3$ & 103.5 \\
\hline \multicolumn{2}{|l|}{ Note: Compiled by the author according to the Ministry of Finance of the Republic of Kazakhstan } \\
\hline
\end{tabular}


The next largest tax revenues are taxes on international trade and foreign operations, which in 2015 amounted to 880 billion KZT, the share in tax revenues of the Republican Budget amounted to (24.6\%), 2016. - 951.8 billion KZT (22.3\%), 2017 - 1,196.9 billion KZT (24.7\%) (Table 5).

Table 5. Analysis of the actual receipt of taxes on international trade and foreign operations in the republican budget in recent years, million KZT

\begin{tabular}{|l|c|c|c|c|}
\hline \multicolumn{1}{|c|}{ Indicators } & $\begin{array}{c}\text { Report for } \\
2015\end{array}$ & $\begin{array}{c}\text { Report for } \\
2016\end{array}$ & $\begin{array}{c}\text { Report for } \\
2017\end{array}$ & $\begin{array}{c}\text { Report for } \\
2018\end{array}$ \\
\hline Revenues & $6,136,968$ & $7,662,220$ & $9,691,789$ & $10,808,573$ \\
\hline Tax revenues, including & $3,332,925$ & $4,275,887$ & 4848028 & $7,890,048$ \\
\hline $\begin{array}{l}\text { Taxes on international trade and foreign } \\
\text { operations }\end{array}$ & 880,063 & 951,807 & $1,196,919$ & $1,422,717$ \\
\hline $\begin{array}{l}\text { The share of taxes on international trade and } \\
\text { foreign operations in RB revenues }\end{array}$ & 14.3 & 12.4 & 12.3 & 13.2 \\
\hline $\begin{array}{l}\text { The share of taxes on international trade and } \\
\text { foreign operations in RB tax revenues }\end{array}$ & 26.4 & 22.3 & 24.7 & 18.0 \\
\hline \multicolumn{7}{|l|}{ Note: Compiled by the author according to the Ministry of Finance of the Republic of Kazakhstan } \\
\hline
\end{tabular}

\section{Discussion}

In general, the analysis of tax revenues indicates the stability of the tax system and the established control and economic work of the tax authorities. If we analyze the audit work over the past two years, it should be noted that the emphasis in administration is aimed at the voluntary fulfillment by the taxpayer of his obligations. Thus, in 2018, according to notifications of desk audit without access to facilities, more than 171 billion KZT was accrued, which is $19 \%$ more than in the previous year (144 billion KZT). Tax assessment efficiency has increased. By notifications 123 billion KZT or 34\% more than in 2017 has been collected.

In the reporting year, it was finally possible to reverse the trend of a decrease in tax revenues relative to GDP. If in 2016 this indicator fell to $15.2 \%$, then last year it already significantly exceeded $16 \%$, against the planned $15.8 \%$. Today, the state revenue authorities have been given the task of increasing the level of consolidated budget revenues to GDP to $25 \%$ by 2025 (Lukpanova, 2017). In the current 2019, it is planned to reach $18 \%$ of GDP.

Thus, the analysis of budget execution for 2014-2018 showed that revenues are increasing from year to year. Basically, the budget is executed at the expense of production taxes, such as CIT, VAT, IIT, for which significant changes have been made in recent years.

Today, tax relations in the republic are regulated by the new Code of the Republic of Kazakhstan "On taxes and other obligatory payments to the budget" (Tax Code), adopted in 2017 (Tax Code of the Republic of Kazakhstan, 2017). Thus, in the tax legislation that entered into force on 01.01.2018, a new principle - the principle of good faith is introduced, which means:

- any inaccuracies or ambiguities, unresolved issues in tax legislation are interpreted in favor of the taxpayer audits

- there will be appropriate justifications (arguments and disclosure of circumstances) in the acts of tax

- fines and penalties were canceled if the taxpayer acted in accordance with the explanation of the tax authority, and subsequently the position of the tax authorities was changed.

In 2019, the marginal income for individual entrepreneurs under a simplified declaration increased to KZT 298 million. In order to develop the infrastructure for the development of non-cash payments, the law also provides an increase in the VAT threshold by 114,184 MCI (minimum calculated indicator) for those working on a simplified declaration, and a marginal income on a simplified declaration by 70,048 MCI. Starting this year, individual entrepreneurs applying a special tax regime based on a patent and a simplified declaration have the opportunity to reduce the amount of IIT in the amount of KZT 60 thousand, but not more than $50 \%$ of the calculated tax amount, if they purchase a new online cash register or a threecomponent integrated system (online cash register + ERP system + POS terminal) [3].

For those who do not meet the criteria for working on a simplified declaration, a new alternative regime has been introduced - Special tax regime using a fixed deduction.

This regime provides for a fixed deduction of $30 \%$ without the availability of supporting documents. A deduction is also provided for the payroll. The tax base will be calculated as the difference between income and expenses, with the obligatory keeping of their records. Moreover, not all expenses and incomes will be 
taken into account, only the most basic ones. Keep in mind that there is a prerequisite - if a fixed deduction is applied, then the amount of expenses should not exceed $70 \%$ of income.

For the application of this regime, higher (compared with the simplified declaration) criteria are established:

- marginal income in the amount of 12,260 times the minimum wage $(346,761,840 \mathrm{KZT})$

- the number of employees in the amount of 50 people.

Tax benefits to subsoil users are provided. With processing ratios of more than $35 \%$, subsoil users are exempted from corporate income tax (CIT) at the source of dividend payment and value growth. The commercial discovery bonus has been canceled, and now subsoil users have the right to compensate for the costs of exploration for one field under other contracts where production began. Based on Russia's experience, Kazakhstan introduced a production tax - mineral extraction tax (MET) (Sembekov, 2016). The introduced subsoil use tax for offshore and deep oil fields is an alternative tax (instead of tax for reimbursement of historical costs, rental tax and excess profit tax). An alternative subsoil use tax has been introduced for offshore and deep oil fields (instead of the mineral extraction tax (MET), historical costs, rental tax and excess profit tax). The excess profit tax has been abolished with the transfer of the burden on coal rental export tax. The MET rate for tin was revised (from $6 \%$ to $3 \%$ ).

If we consider the experience of Russia, the tax policy in 2010-2013, on the one hand, was aimed at counteracting the negative effects of the economic crisis, and on the other hand, at creating conditions for restoring positive rates of economic growth. The main directions of the development of the tax system and improvement of the tax policy of the Russian Federation during this period were support for investment and the development of human capital.

Preferential taxation has been introduced for certain categories of taxpayers. Thus, entrepreneurs have the right to reduce the amount of CIT by $100 \%$ if they carry out the following activities:

- electronic trade in goods;

- transportation of cargo by a ship registered in the international ship registry of the Republic of Kazakhstan;

- Activities for the organization and holding of an international specialized exhibition in the Republic of Kazakhstan.

There are a lot of changes in tax legislation:

- the number of tax audits is reduced;

- new deductions and types of income are added;

- the conditions for the application of benefits have been expanded for FEZ participants;

- part of ineffective VAT benefits are canceled;

- VAT refund procedures are changed;

- Amendments regarding exports to the EAEU countries are made;

- places of sale have been supplemented in order to calculate VAT;

- and many more different amendments. However, there are still many problems left overboard (Shakirova, 2019).

Let's consider the most pressing problems to date. One of the problems is that enterprises operating in the production infrastructure and produce regionally significant products do not have additional tax benefits. While nowadays this is just necessary, since the most developed activities in our country are trade and intermediary activities, and entities in the manufacturing sector and non-resource sector of the economy are the least involved (Sembekov, 2016).

Another problem is the lack of tax benefits for domestic entrepreneurs producing import-substituting products. We have a lot of high-quality domestic products, especially among food products, but, unfortunately, they do not withstand price and other competition, since there are no special incentives for them from state support, including tax benefits.

Also, in the tax legislation there are practically no methods and mechanisms for stimulating innovation (R\&D), that is, for organizations engaged in new technologies and creating new scientific and technical developments there are practically no tax features compared to enterprises in other industries. For example, many countries have established special taxation regimes for subjects of scientific and innovative activities, as a result of which these countries have developed the production of new products, the production of new manufacturing, technological, household, computer and other equipment that meets modern requirements. 
To solve these problems it is necessary to:

- stimulate manufacturers (producing regionally significant or import-substituting products) with additional tax incentives;

- establish an attractive (simplified) taxation regime for subjects of scientific and innovative activities in order to stimulate science-intensive and high-tech industries, provide tax incentives to individuals who invest in domestic production;

- create stimulating tax conditions for taxation of scientific and technological discoveries, as it is done in many foreign countries.

\section{Conclusion}

Thus, the application of tax benefits should not be limited to lowering tax rates. It is necessary to apply a reduction factor for innovative products and production profitable enterprises. In the world practice, a tax investment loan is used as a benefit, i.e. deduction from the income tax of a part of the company's investment expenses (often subject to the use of this loan for subsequent investments). That is, in the context of the growing dependence of the state budget of the Republic of Kazakhstan on the taxation of the commodity sector against the background of negative dynamics in prices on world commodity markets, there is a need to study new trends and problematic issues that may affect the development of the tax system in Kazakhstan in the future.

There is also a need to pursue a policy to stimulate the production of agricultural processing enterprises and the food industry, and to understand the specifics of agriculture - the main supplier of raw materials for these industries. Meanwhile, producers understand that co-production on the local market can come from many countries. Thus, the need has arisen for changing tax legislation in favor of food producers, in particular, reducing the tax burden on value added tax.

The application of a similar taxation scheme for this industry will significantly reduce the tax burden on enterprises processing agricultural raw materials. Accordingly, these funds can be used for investment and reinvestment of own fixed assets, which will lead to a reduction in the cost of processed products offered to consumers.

Thus, to summarize it should be noted that in the future it is necessary to direct tax incentives to create a favorable investment climate in Kazakhstan, reduce the overall tax burden on the non-resource sectors of the economy, and resolve administrative issues that impede the free development of private enterprise. The implementation of the above tasks to improve tax legislation will contribute to the modernization and diversification of the economy, which will increase the competitiveness of the economy of Kazakhstan.

\section{References}

Banelene, R., Melnikas, B., Strazdas, R., Tolochka, E. (2018). Innovation and the impact of R\&D investment on economic growth: assessment and modeling. TERRA ECONOMICUS. 16, 66-76.

Chaplinska, A., Assanova, M.K., Orymbekova, R.A., Shevyakova, A.L. (2016). Nalogovaya nagruzka v Respublike Kazahstan [Tax rate in the Republic of Kazakhstan]. Vestnik Karagandinskogo Universiteta. Serija Ekonomika Bulletin of the Karaganda University. Economy Series. 2(82), 248-254. [in Russian].

Diamond, J. (2003) From Program To Performance Budgeting: The Challenge For Emerging Economies. IMF Working Paper Series, 3(169), 26-28.

Feehan, J.P., Matsumoto, M. (2002). Distortionary Taxation and Optimal Public Spending on Productive Activities. Economic Inquiry, 1, 60-68.

Fiorella Fiore, Werner Roeger. (1999). Growth and employment effects of fiscal regimes. Oxford Economic Papers, 51, 200-222.

Jorgenson, D.W. (2001). Investment. Lifting the burden: Tax reform, the cost of capital and U.S economic growth, 474 p. London: MIT Press

Keynes, John Maynard (1936). The General Theory of Employment, Interest and Money. London: Macmillan (reprinted 2007).

Kodeks Respubliki Kazahstan (2017) “O nalogah i drugih obyazatel'nyh platezhah v byudzhet”. [Code of the Republic of Kazakhstan "On taxes and other obligatory payments to the budget”] [in Russian]

Lukpanova, Zh.O., Kudaibergenova, S. K., Sembekov, A.K., Uiakov, N.S., Iglikova, D.D., Mukasheva, K.A. (2017). Harmonization and tax stimulation of innovative activity of Kazakhstan in the EEU. Journal of Advanced Research in Law and Economics, 4(26), 1193-1199

Oficial'nyj sajt Ministerstva finansov Respubliki Kazahstan [Official website of the Ministry of Finance of the Republic of Kazakhstan]: http:// www.minfin.gov.kz) [in Russian] 
Rosenthal, S. (2017). Slashing Corporate Taxes: Foreign Investors Are Surprise Winners: https://www.taxpolicycenter--org/publications/slashing-corporate-taxes-foreign-investors-are-surprise-winners/

Samuelson, Paul A. (1952), Economic Theory and Mathematics - An Appraisal. American Economic Review, 42(2), $56-66$.

Sembekov, A.K., Lukpanova, Zh.O. (2016). Analiz reformirovaniya nalogovoy sistemy Respubliki Kazakhstan v usloviyakh integratsii v EAES [Analysis of reform the tax system of the Republic of Kazakhstan in conditions of integration into the EEU]. Vestnik Karagandinskogo Universiteta. Serija Ekonomika - Bulletin of the Karaganda University. Economy Series. 2(82), 255-261. [in Russian].

Sembekov, A.K., Serikova, G.S., Lukpanova, Zh.O., Sembekov, E.A., Uiakov, N.S., Shakirova, A. (2016). Questions of Tax Harmonization in EAEC countries. International Journal of Environmental \& Science Education, vol. 11, no. 18, $11119-11125$

Shakirova, G.A., Sitenko, D.A., Vasa. L. (2019). Audit effektivnosti ispol'zovaniya byudzhetnyh sredstv v processe provedeniya gosudarstvennogo audita [Audit of efficiency of the use of budgetary funds in the process of conducting a state audit]. Vestnik Karagandinskogo Universiteta. Serija Ekonomika - Bulletin of the Karaganda University. Economy Series. 2(94), 262-274. [in Russian].

Toye J. (2000). Fiscal crisis and fiscal reform in developing countries. Cambridge Journal of Economics, 24, 21-44

\section{А.К. Сембеков, Ж.О. Лукпанова, Ж.А. Тойжигитова, Н.Н. Тюпакова \\ Жаңғырту жағдайындағы Қазақстан Республикасының салық саясаты}

\section{Aңдаmna}

Maқcambl: Зерттеудің мақсаты өткізілген салық реформаларының нәтижелерін анықтаудан, Қазақстан Республикасының салық жүйесінің қазіргі таңдағы жағдайын бағалаудан, сонымен қатар Қазақстан салық жүйесінің мәселелерін айқындап, жетілдірудің негізгі бағыттарын анықтаудан тұрады.

Әдісі: Зерттеу әдістері - жүйелі талдау, мәліметтерді экономикалық және статистикалық өңдеу, салыстыру мен жалпылау, ғылыми талдау мен жинақтау.

Қорытынды: Мақалада Қазақстан Республикасында өткізілетін заманауи салық саясатының, атап айтқанда соңғы салықтық түрлендірулер екпінімен Қазақстан экономикасына салық реформаларының әсеріне талдау жүргізілген. Корпоративті табыс салығы, қосылған құн салығы, халықаралық саудаға және сыртқы операцияларға салынатын салық сияқты негізгі салықтарға баса назар аудара отырып, салық түсімдерінің және соңғы жылдардағы бюджеттегі құрылымдық өзгерістердің салыстырмалы талдауы жүзеге асырылған.

Тұжырымдама: Зерттеу нәтижесінде заманауи талаптарға сәйкестігі тұрғысынан Қазақстандағы салық реформаларының нәтижелілік мәселелері анықталған. Мақалада Қазақстанның қазіргі таңдағы салық саясаты шағын және орта бизнес субъектілерін қолдауға, экономиканың шикізаттық емес секторын ынталандыруға бағытталуы тиіс екені жайлы айтылған. Әсіресе, қосылған құн салығын төмендету бөлігінде азық-түлік өнімдерін өндірушілерді салықтық ынталандырудың қажеттілігі негізделіп, азық-түлік өнеркәсібі мен ауыл шаруашылық шикізатын қайта өңдеу өнеркәсіптерінің өнімдерін ынталандыру бойынша саясатын жүргізу ұсынылған. ЕАЭО интеграциялық саудасының жағдайында одақтың әкімшілік және кедендік мәселелерін шешу, экономиканың шикізаттық емес секторының өнімдеріне жалпы салық жүктемесін азайту бойынша салық ынталандырмасын қабылдау қажет.

Кілm сөздер: салық реформалары, салықтық түсімдер, салық жеңілдіктері, бюджеттік кірістер, салық мөлшерлемесі, салықтар, салықтық саясат, кіріс.

\section{А.К. Сембеков, Ж.О. Лукпанова, Ж.А. Тойжигитова, Н.Н. Тюпакова Налоговая политика Республики Казахстан в условиях модернизации}

\section{Аннотация}

Цель: Цель исследования состоит в выявлении результатов проведенных налоговых реформ, оценке современного состояния налоговой системы Республики Казахстан, а также проблем и определении основных направлений совершенствования налоговой системы Казахстана.

Meтоды: Методы исследования: системный анализ, экономико-статистическая обработка данных, сравнения и обобщения, научного анализа и синтеза.

Результаты: В статье проведен анализ современной налоговой политики, проводимой в Республике Казахстан, а именно влияния налоговых реформ на экономику Казахстана, с акцентом на последние налоговые преобразования. Проведен анализ налоговых поступлений и сравнительный анализ структурных изменений в бюджете за последние годы, с акцентом на основные производственные налоги, такие как корпоративный подоходный налог, налог на добавленную стоимость, налоги на международную торговлю и внешние операции.

Bыводы: В результате исследования раскрыты проблемы результативности налоговых реформ в Казахстане с позиций их соответствия современным требованиям. В статье отмечено, что современная налоговая поли- 
тика Казахстана должна быть направлена на поддержку субъектов малого и среднего бизнеса, стимулирование несырьевого сектора экономики. В частности, предлагается проведение политики по стимулированию продукции предприятий по переработке сельхозсырья и пищевой промышленности, обоснована необходимость налогового стимулирования производителей пищевой продукции, в части снижения налога на добавленную стоимость. В условиях интеграционной торговли ЕАЭС необходимо принять налоговые стимулы по снижению общей налоговой нагрузки на продукты несырьевого сектора экономики, разрешению административнотаможенных проблем союза.

Ключевые слова: налоговые реформы, налоговые поступления, налоговые льготы, доходы бюджета, ставка налога, налоги, налоговая политика, доход.

\section{References}

Banelene R. Innovation and the impact of R\&D investment on economic growth: assessment and modeling [Tекст] / R. Banelene, B. Melnikas, R. Strazdas, E. Tolochka // TERRA ECONOMICUS. — 2018. — № 16. — C. 66-76.

Diamond J. From Program To Performance Budgeting: The Challenge For Emerging Economies [Tекст] / J. Diamond // IMF Working Paper Series. — 2003. - № 3(169). - C. 26-28.

Feehan J.P. Distortionary Taxation and Optimal Public Spending on Productive Activities [Tекст] / J.P. Feehan, M. Matsumoto // Economic Inquiry. — 2002. — № 1. - C. 60-68.

Fiorella Fiore. Growth and employment effects of fiscal regimes [Текст] / Fiore Fiorella, Roeger Werner // Oxford Economic Papers. — 1999. - № 51. - C. 200-222.

Jorgenson D.W. Investment. Lifting the burden: Tax reform, the cost of capital and U.S economic growth [Tекст] / D.W. Jorgenson // London: MIT Press. - 2001. - C. 474.

Keynes John Maynard The General Theory of Employment, Interest and Money [Текст] / John Maynard Keynes // London: Macmillan. — 1936. — (reprinted 2007)

Lukpanova Zh.O. Harmonization and tax stimulation of innovative activity of Kazakhstan in the EEU [Tекст] / Zh.O. Lukpanova, S. K. Kudaibergenova, A.K. Sembekov, N.S. Ulakov, D.D. Iglikova, K.A. Mukasheva // Journal of Advanced Research in Law and Economics. — 2017. — № 4(26). — C. 1193-1199.

Rosenthal S. Slashing Corporate Taxes: Foreign Investors Are Surprise Winners. - $2017 . \quad-$ (https://www.taxpolicycenter--org/publications/slashing-corporate-taxes-foreign-investors-are-surprise-winners/)

Samuelson Paul A. Economic Theory and Mathematics - An Appraisal [Текст] / Paul A. Samuelson // American Economic Review. - 1952. — № 42(2). - C. 56-66.

Sembekov A.K. Questions of Tax Harmonization in EAEC countries [Текст] / A.K. Sembekov, G.S. Serikova, Zh.O. Lukpanova, E.A. Sembekov, N.S. Ulakov, A. Shakirova// International Journal of Environmental \& Science Education. - 2016. — № 18. - C. - 1119-1125.

Toye J. Fiscal crisis and fiscal reform in developing countries [Текст] / J. Toye // Cambridge Journal of Economics. 2000. - № 24. - C. 21-44.

Кодекс Республики Казахстан «О налогах и других обязательных платежах в бюджет (Налоговый кодекс)» от 25 декабря 2017 года № 120-VI ЗРК. Официальный сайт Министерства финансов Республики Казахстан. - (http:// www.minfin.gov.kz)

Сембеков А.К. Анализ реформирования налоговой системы Республики Казахстан в условиях интеграции в ЕАЭС [Текст] / А.К. Сембеков, Ж.О. Лукпанова // Вестн. Караганд. ун-та. Сер. Экономика. — 2016. № 2(82). - C. 255-261.

Чаплинска А. Налоговая нагрузка в Республике Казахстан [Текст] / А. Чаплинска, М.К. Асанова, Р.А. Орымбекова, А.Л. Шевякова // Вестн. Караганд. ун-та. Сер. Экономика. — 2016. — № 2(82). — С. 248-254.

Шакирова Г.А. Аудит эффективности использования бюджетных средств в процессе проведения государственного аудита [Текст] / Г.А. Шакирова, Д.А. Ситенко, Л.Васса // Вестн. Караганд. ун-та. Сер. Экономика. 2019. — № 2(94). — C. 262-274. 